\title{
Pengaruh Pembiayaan Bagi Hasil dan Pembiayaan Sewa terhadap Laba Bersih PT. Bank Syariah Mandiri
}

\author{
Siti Aisyah Siregar \\ Program Studi Akuntansi, Fakultas Ekonomi dan Bisnis UMSU \\ Email : sitiaisyah@umsu.ac.id
}

\begin{abstract}
Abstract: Based on the type of problem studied, the research approach used is associative. The data collection technique used is the study of documentation by collecting data derived from the monthly financial statements of PT Bank Syariah Mandiri in 2017-2019. The data analysis technique used in this study is multiple linear regression. The research result is known that partially variable profit sharing financing has no effect and is insignificant to net profit. In addition, partially variable lease financing has no effect and signifies net profit. While simultaneously variable profit sharing financing and lease financing have a significant influence on net profit.
\end{abstract}

Keyword: revenue sharing financing, lease financing, net income.

\section{Pendahuluan}

Pertumbuhan perekonomian tentu saja akan memiliki kaitan yang erat dengan kondisi keuangan suatu negara serta peran dari perbankan dalam melakukan aktivitas operasionalnya dengan baik dan juga lancar. Kita ketahui bahwa di beberapa tahun terakhir ini perekonomian Indonesia sedang berada dalam kondisi yang kurang baik. Salah satu peran perbankan yaitu sebagai lembaga intermediasi yang memiliki perananan yang sangat penting. Bank sebagai lembaga intermediasi keuangan selain melakukan kegiatan penghimpunan dana dari masyarakat, ia juga menyalurkan dana tersebut ke masyarakat dalam bentuk kredit atau pembiayaan (Umam, 2016:101)

Perkembangan dunia perbankan di Indonesia mengalami kemajuan yang sangat pesat, terkhusus pada perbankan yang berprinsip syariah. Hal ini terjadi dikarenakan telah berkembangnya pemahaman para masyarakat terkait dengan sistem syariah yang tidak menggunakan bunga (riba). Semakin maraknya masyarakat menggunakan bank syariah dapat kita lihat dengan adanya berbagai macam tawaran produk pembiayaan yang disalurkan kepada masyarakat, selain itu juga bertambahnya jaringan kantor perbankan syariah di Indonesia dari tahun ke tahun, termasuk perkembangan yang terjadi pada kantor PT. Bank Syariah Mandiri.

Menurut Muhammad (2011: 86), berdasarkan tingkat kepastian dari hasil yang diperolehnya, kontrak bisnis dapat dibedakan menjadi dua kelompok yaitu Natural Uncertainty Contracts (NUC) dan Natural Certainty Contracts (NCC). Natural Uncertainty Contracts adalah kontrak dalam bisnis yang tidak memberikan kepastian pendapatan baik dari segi jumlah maupun waktunya, yang termasuk dalam kelompok ini yaitu kontrak mudharabah, musyarakah, dan lain-lain. Sedangkan Natural Certainty Contracts adalah kontrak dalam bisnis yang memberikan kepastian pembayaran baik dari segi jumlah maupun waktu, yang termasuk dalam kelompok ini yaitu kontrak jual beli, sewa-menyewa dan lainlain.

Pembiayaan bagi hasil (mudharabah dan musyarakah) merupakan pembiayaan yang disalurkan oleh bank kepada nasabah dan menghasilkan pendapatan yang nantinya akan 
dilakukan dalam bentuk pembagian hasil sesuai kesepakatan yang telah disepakati di awal akad. Pendapatan yang telah diterima oleh bank dari bagi hasil dengan nasabah akan mempengaruhi besarnya laba bersih bank. Pembiayaan bagi hasil juga kemungkinan tidak menghasilkan keuntungan, hal ini bisa saja disebabkan karena setiap dana yang disalurkan oleh bank dalam bentuk pembiayaan bagi hasil tidak selalu mengalami keberhasilan yang mendatangkan keuntungan. Kerugian yang dialami oleh bank akan berpengaruh terhadap perubahan aset dan laba bersih Bank Syariah Mandiri.

Pembiayaan sewa merupakan penyaluran dana yang berkaitan dengan sewa menyewa, di mana bank akan diakui sebagai pemilik objek sewa dan nasabah sebagai penyewa. Pembiayaan sewa akan menghasilkan keuntungan yang bersifat pasti, sebab bank akan memperoleh keuntungan dari besarnya biaya sewa yang telah disepakati dengan nasabah pada saat awal akad dilakukan. Besarnya pendapatan yang diperoleh bank dari pembiayaan sewa akan berpengaruh terhadap perubahan laba bersih PT. Bank Syariah Mandiri, selain itu pembiayaan yang berpotensi menghasilkan keuntungan maupun tidak menghasilkan keuntungan tentu saja akan berpengaruh terhadap laba bersih yang diperoleh bank. Pembiayaan yang mengalami kemacetan atau mengalami suatu kerugian akan mengakibatkan laba bersih bank mengalami penurunan. Laba bersih akan mengalami peningkatan ketika pembiayaan-pembiayaan yang disalurkan kepada nasabah mampu menghasilkan keuntungan yang tinggi, semakin tinggi pembiayaan yang disalurkan maka semakin tinggi pula pendapatan yang diterima oleh bank dan akan mengakibatkan laba bersih PT. Bank Syariah Mandiri.

Dalam penelitian ini objek yang digunakan yaitu PT. Bank Syariah Mandiri yang merupakan salah satu bank di Indonesia yang menerapkan prinsip syariah dan juga dikenal mengalami perkembangan kinerja sangat baik. Sehingga dapat dikatakan bahwasanya PT. Bank Syariah Mandiri merupakan salah satu tolak ukur dalam penilaian kinerja keuangan bank syariah yang ada di Indonesia.

Tabel 1.1

Pembiayaan Bagi Hasil, Pembiayaan Sewa, dan Laba Bersih PT. Bank Syariah Mandiri Periode 2017-2018 (dalam jutaan rupiah)

\begin{tabular}{|c|c|c|c|}
\hline Tahun & $\begin{array}{c}\text { Pembiayaan } \\
\text { Bagi Hasil }\end{array}$ & $\begin{array}{c}\text { Pembiayaan } \\
\text { Sewa }\end{array}$ & Laba Bersih \\
\hline 2017 & 21.038 .964 & 13.706 & 365.166 \\
2018 & 24.722 .107 & 1.264 & 605.213 \\
2019 & 28.500 .574 & 1.567 & 1.275 .034 \\
\hline
\end{tabular}

Berdasarkan tabel di atas, kita dapat melihat secara umum seperti apa perkambangan beberapa pembiayaan dan laba bersih pada PT. Bank Syariah Mandiri. Pada tabel di atas, pembiayaan bagi hasil (mudharabah dan musyarakah) pada tahun 2018 mengalami peningkatan dari tahun 2017 sebesar Rp 24.722.107 juta dan tahun 2019 juga mengalami peningkatan sebesar Rp 28.500.574 juta. Peningkatan pembiayaan bagi hasil ini bisa saja disebabkan tingginya minat masyarakat walau tingkat resiko juga cukup tinggi. Sedangkan pembiayaan sewa jika kita lihat dari tabel di atas mengalami penurunan yang sangat drastis yaitu pada tahun 2018 sebesar Rp 1.264 juta dibandingkan dengan tahun 2017 yaitu berjumlah sebesar Rp 13.706 juta, sedangkan di tahun 2019 mengalami kenaikan kembali sebesar Rp 1.567 juta. Selain itu juga dapat dilihat pada tabel bahwa laba bersih PT. Bank Syariah Mandiri selalu mengalami peningkatan, seperti pada tahun 2018 sebesar Rp 605.213 juta meningkat dari tahun sebelumnya pada tahun 2017 sebesar Rp 365.166 juta dan tahun 2019 meningkat sebesar 1.275.034 juta. Diketahui tujuan utama PT. Bank Syariah yaitu untuk mendapatkan 
keuntungan atau laba yang maksimal, begitu pula dengan tujuan dari PT. Bank Syariah Mandiri agar dapat selalu meningkatkan kinerjanya.

Pembiayaan yang memperoleh keuntungan ataupun tidak memperoleh suatu keuntungan tentu saja pada akhirnya akan mempengaruhi tingkat laba bersih yang diperoleh. Dengan kata lain yaitu semakin tinggi pembiayaan-pembiayaan yang disalurkan maka akan semakin tinggi pendapatan yang diterima oleh bank. Peningkatan pendapatan tersebut akan berpengaruh pada tingkat laba atau keuntungan. Pada PT. Bank Syariah Mandiri pembiayaan bagi hasil dan pembiayaan sewa mengalami fluktuasi, khususnya pembiayaan sewa yang mengalami penurunan drastis pada tahun 2018. Walaupun hal ini terjadi, tapi ternyata laba bersih yang diterima oleh PT. Bank Syariah Mandiri tidak mengalami penurunan.

Adapun penelitian ini mengacu pada penelitian sebelumnya yang telah dilakukan oleh Rantisa (2016) menunjukkan bahwa pembiayaan bagi hasil secara parsial tidak berpengaruh positif terhadap peningkatan laba bank umum syariah, dan pembiayaan sewa secara parsial berpengaruh positif terhadap peningkatan laba bank umum syariah. Sedangkan secara simultan pembiayaan bagi hasil dan sewa berpengaruh positif terhadap laba bank umum syariah. Berdasarkan uraian tersebut dan juga beberapa hasil penelitian sebelumnya mengenai pembiayaan yang mempengaruhi laba bersih ternyata berbeda-beda, maka penulis ingin melakukan penelitian kembali untuk memperoleh bukti empiris yang dapat memberikan manfaat bagi pihak-pihak yang berkepentingan. Penelitian ini dimaksudkan untuk mengetahui seberapa besar pengaruh pembiayaan bagi hasil dan sewa terhadap laba bersih PT. Bank Syariah Mandiri pada tahun 2017 sampai 2019.

\section{Kajian Teori}

\subsection{Laba Bersih}

Menurut PSAK Nomor 1 informasi laba diperlukan untuk menilai perubahan potensi sumberdaya ekonomis yang mungkin dapat dikendalikan di masa depan menghasilkan arus kas dari sumber daya yang ada, dan untuk perumusan pertimbangan tentang efektivitas perusahaan dalam memanfaatkan tambahan sumber daya. Bagi pemilik saham dan atau investor, laba berarti peningkatan nilai ekonomis yang akan diterima, melalui pembagian dividen. Laba juga digunakan sebagai alat untuk mengukur kinerja manajemen perusahaan selama periode tertentu yang pada umumnya menjadi perhatian pihak-pihak tertentu terutama dalam menaksir kinerja atas pertanggungjawaban manajemen dalam pengelolaan sumberdaya yang dipercayakan kepada mereka, serta dapat dipergunakan untuk memperkirakan prospeknya di masa depan.

Laba bersih merupakan laba yang telah dikurangi biaya-biaya yang menjadi beban perusahaan di dalam suatu periode tertentu termasuk pajak. Laba bersih adalah hasil dari kinerja perusahaan selama periode waktu tertentu. Hasil bersih kinerja perusahaan yang telah dikurangi dengan berbagai macam beban termasuk ialah beban pajak. Hasil bersih tersebut yang dimaksudkan yaitu laba bersih ketika pendapatan lebih besar dibanding beban.

Menurut Suaidah (2020) ada beberapa faktor yang mempengaruhi perubahan laba bersih, yaitu naik turunnya jumlah unit yang dijual dan harga jual per unit, naik turunnya dari harga pokok penjualan, naik turunnya biaya usaha yang dipengaruhi oleh jumlah unit yang dijual, dan naik turunnya biaya non operasional yang dipengaruhi oleh variasi jumlah unit yang dijual.

Menurut Sari (2018 : 46) perhitungan laba merupakan hal yang sangat penting bagi perusahaan karena memiliki beberapa tujuan. Secara interen besar kecilnya laba yang dihasilkan oleh sebuah perusahaan merupakan dasar yang menjadi petunjuk tentang kualitas pimpinan perusahaan, selain itu laba yang dihasilkan perusahaan merupakan bahan analisis untuk perusahaan periode di masa mendatang. Sedangkan secara ekstern laba akan dijadikan sebagai bahan pertanggung jawaban dan perhitungan para pemegang saham, pajak, emisi 
saham di bursa efek dan sebagai bahan perimbangan permohonan kredit (pembiayaan) pada bank-bank lain.

Menurut Zainuddin (2020) laporan laba rugi yang terdapat pada sebuah bank syariah terdapat tiga unsur utama yaitu :

a. Penghasilan (income) yaitu merupakan naiknya suatu manfaat ekonomi dalam suatu periode akuntansi yang berbentuk pemasukan atau penambahan aset atau sebalaiknya penurunan angka liabilitas yang mengakibatkan kenaikan ekuitas yang tidak berasal dari kontribusi penanam modal. Penghasilan (income) meliputi baik pendapatan (evenues) ataupun keuntungan (gains). Pendapatan yang ada karena aktivitas utama entitas syariah seperti margin penjualan, ujrah sewa, bagi hasil, dan fee jasa. Sedangkan keuntungan mencerminkan pos lainnya yang memenuhi kriteria penghasilan akan tetapi bukan merupakan aktivitas utama.

b. Hak Pihak Ketiga atas Bagi hasil Dana Syikah Temporer yaitu merupakan bagian dari bagi hasil pemilik dana atas keuntungan dari kerugian investasi bersama entitas syariah dalam periode suatu laporan keuangan. Unsur ini tidak bisa dikelompokkan sebagai unsur suatu beban (pada saat mengalami keuntungan) atau pendapatan (ketika rugi). Namun hak pihak ketiga atas bagi hasil merupakan alokasi keuntungan dan kerugian kepada pemilik dana atas investasi yang dilakukan bersama entitas bank.

c. Beban (expenses) merupakan sebuah manfaat ekonomi yang mengalami penurunan selama masa periode akuntansi dalam bentuk arus kas keluar atau berkurangnya aset atau terjadinya liabilitas yang mengakibatkan penurunan ekuitas yang tidak menyangkut pembagian kepada penanam modal.

\subsection{Pembiayaan Bagi Hasil}

Perlu dipahami bahwa pembiayaan bagi hasil ini merupakan suatu sistem yang di dalamnya terdapat tata cara pembagian hasil usaha antara penyedia dana (shahibul maal) dan pengelola dana (mudharib). Prinsip bagi hasil dapat dinyatakan sebagai suatu langkah yang inovatif pada lembaga keuangan syariah karena memiliki unsur keadilan, sehingga tidak ada pihak yang dirugikan dan diuntungkan antara penyedia dana (shahibul maal) dan pengelola dana (mudharib).

Menurut Arif (2012 : 101) pembiayaan dengan prinsip bagi hasil digunakan untuk usaha kerja sama yang bertujuan untuk mendapatkan barang dan jasa sekaligus, di mana tingkat keuntungan bank ditentukan dari besarnya keuntungan usaha sesuai dengan prinsip bagi hasil. Pada produk bagi hasil keuntungan ditentukan oleh nisbah bagi hasil yang disepakati di muka. Produk perbankan yang termasuk dalam kelompok ini dan yang sering digunakan dala pembiayaan perbankan adalah mudharabah dan musyarakah.

Pembiayaan mudharabah merupakan akad pembiayaan antara bank syariah sebagai pengelola modal (shahibul mal) dan nasabah sebagai pengelola (mudharib) untuk melaksanakan kegiatan usaha, di mana bank syariah memberikan modal sebanyak $100 \%$ dan nasabah menjalankan usahanya. Hasil usaha atas pembiayaan mudharabah akan dibagi antara bank syariah dan nasabah dengan nisbah bagi hasil yang telah disepakati pada saat akad. Apabila pengelolaan nasabah berhasil mendapatkan keuntungan, maka bank syariah akan memperoleh keuntungan dari bagi hasil yang diterima. Sebaliknya jika nasabah gagal menjalankan usahanya dan mengakibatkan kerugian, maka seluruh kerugian ditanggung oleh shahibul maal. Mudharib tidak menanggung kerugian sama sekali atau tidak ada kewajiban untuk mennaggung kerugian atas kegagalan usaha tersebut (Ismail, 2014 : 168).

Pembiayaan musyarakah merupakan akad kerja sama usaha antara dua pihak atau lebih dalam menjalankan usaha, di mana masing-masing pihak menyertakan modalnya sesuai dengan kesepakatan, dan bagi hasil atas usaha bersama diberikan sesuai dengan kontribusi dana atau sesuai kesepakatan bersama. Musyarakah disebut juga dengan syrikah, merupakan aktivitas berserikat dalam melaksanakan usaha bersama antara pihak-pihak tersebut. Hasil usaha atas mitra usaha dalam syirkah akan dibagi sesuai dengan nisbah yang telah disepakati 
oleh pihak-pihak yang berserikat. (Ismail, $2016: 176$ )

\subsection{Pembiayaan Sewa}

Pembiayaan dengan prinsip sewa dilandasi dengan adanya perpindahaan manfaat. Jadi pada dasarnya prinsip sewa sama saja dengan prinsip jual beli, tetapi perbedaannya terletak pada objek transaksinya. Apabila pada jual beli objek transaksinya adalah berupa barang, pada sewa objek transaksinya adalah jasa. Menurut Siamat akad yang banyak digunakan dalam prinsip sew adalah al-Ijarah dan al-Ijarah al-Muntahia Bit-tamlik (IMBT).

Ijarah merupakan transaksi kontrak sewa antara pihak yang menyewakan dan pihak penyewa, di mana pihak penyewa harus membayar sewa sesuai dengan perjanjian, dan pada saat jatuh tempo aset yang disewa harus dikembalikan kepada pihak yang menyewakan. Biaya pemeliharaan atas aset yang menjadi objek sewa merupakan tanggungan pihak yang menyewakan. Sedangkan Ijarah Muntahiya Bit-tamlik (IMBT) merupakan perjanjian sewa antara pihak pemilik aset tetap (lessor) dan penyewa (lessee) atas barang yang disewakan, dan penyewa mendapatkan hak opsi untuk membeli objek sewa pada saat masa sewa berakhir (Ismail, $2016: 160$ )

\subsection{Kerangka Konseptual}

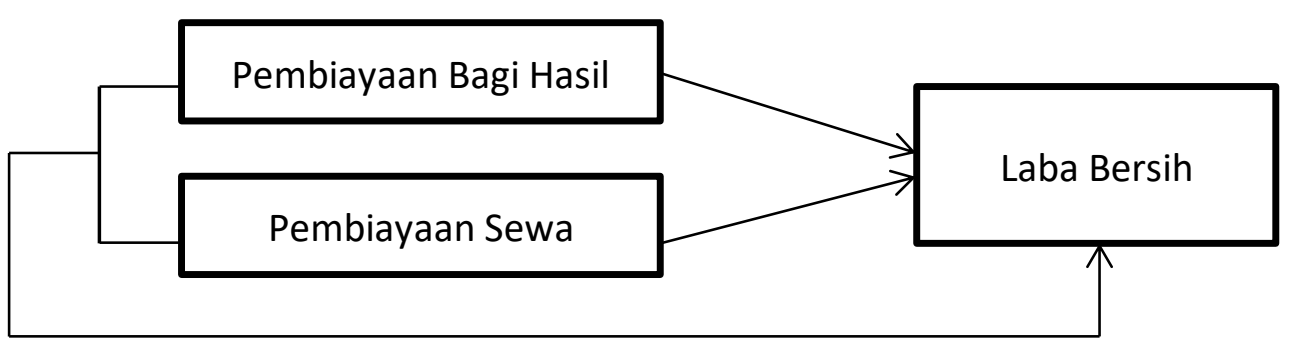

Gambar 2.1

Kerangka Konseptual

\subsection{Hipotesis Penelitian}

Berdasarkan masalah penelitian dan kerangka konseptual yang telah dikembangkan sebelumnya, maka dapat dirumuskan hipotesis sementara sebagai berikut :

a. Pembiayaan Bagi Hasil berpengaruh terhadap Laba Bersih Bank Syariah Mandiri

b. Pembiayaan Sewa berpengaruh terhadap Laba Bersih Bank Syariah Mandiri

c. Pembiayaan Bagi Hasil dan Pembiayaan Sewa berpengaruh terhadap Laba Bersih Bank Syariah Mandiri

\section{Metode Penelitian}

Penelitian ini merupakan penelitian desain kausal yang bertujuan untuk mengetahui pengaruh antara dua variabel atau lebih. Jenis data yang digunakan adalah data kuantitatif. Sumber data berasal dari laporan keuangan bulanan yang diterbitkan oleh Bank Syariah Mandiri. Tujuan penelitian ini adalah untuk menguji dan menggambarkan pengaruh pembiayaan bagi hasil dan pembiayaan sewa terhadap laba bersih yang ada pada Bank Syariah Mandiri periode 2017 sampai 2019. Teknik analisis yang digunakan dalam penelitian ini adalah Penelitian ini menggunakan metode analisis statistik dengan model regresi linier berganda yaitu berfungsi untuk menguji pengaruh antara variabel independen terhadap variabel dependen.Persamaan regresi linier berganda pada penelitian ini adalah sebagai berikut :

$$
\mathbf{Y}=\mathbf{a}+\mathbf{b}_{1} \mathbf{X}_{1}+\mathbf{b}_{2} \mathbf{X}_{2}+\mathbf{e}
$$

Keterangan : 
$\mathrm{Y}=$ Laba Bersih

$\mathrm{X}_{1}=$ Pembiayaan Bagi Hasil

$\mathrm{X}_{2}=$ Pembiayaan Sewa

$\mathrm{b}_{1}=$ Koefisien pembiayaan Bagi Hasil Bank Syariah Mandiri

$\mathrm{b}_{2}=$ Koefisien pembiayaan Sewa Bank Syariah Mandiri

$\mathrm{a}=$ Konstanta

e $=$ Standar eror

\section{Hasil Dan Pembahasan}

\subsection{Hasil Penelitian}

Hasil penelitian menyajikan deskripsi data penelitian yang menggambarkan nilai minimum dan nilai maksimum dari variabel penelitian dengan uraian yang singkat dan jelas.

1. Uji Normalitas

Menurut Ghozali (2009) uji normalitas bertujuan untuk menguji apakah data yang digunakan dalam model regresi variabel independen dan variabel dependen telah berdistribusi secara normal atau tidak. Apabila dilakukan penelitian dengan analisis statistik one-Sampel Kolmogorov-Smirnov test yaitu dengan tingkat signifikansi 0,05 , jika signifikan $\leq 0,05$ maka data tidak berdistribusi normal. Uji normalitas data dilakukan dengan alat uji non parametrik Kolmorgov-smirnov, seperti yang terlihat pada tabel 1 berikut ini :

Tabel 4.1

Hasil Uji Kolmogorov-Smirnov

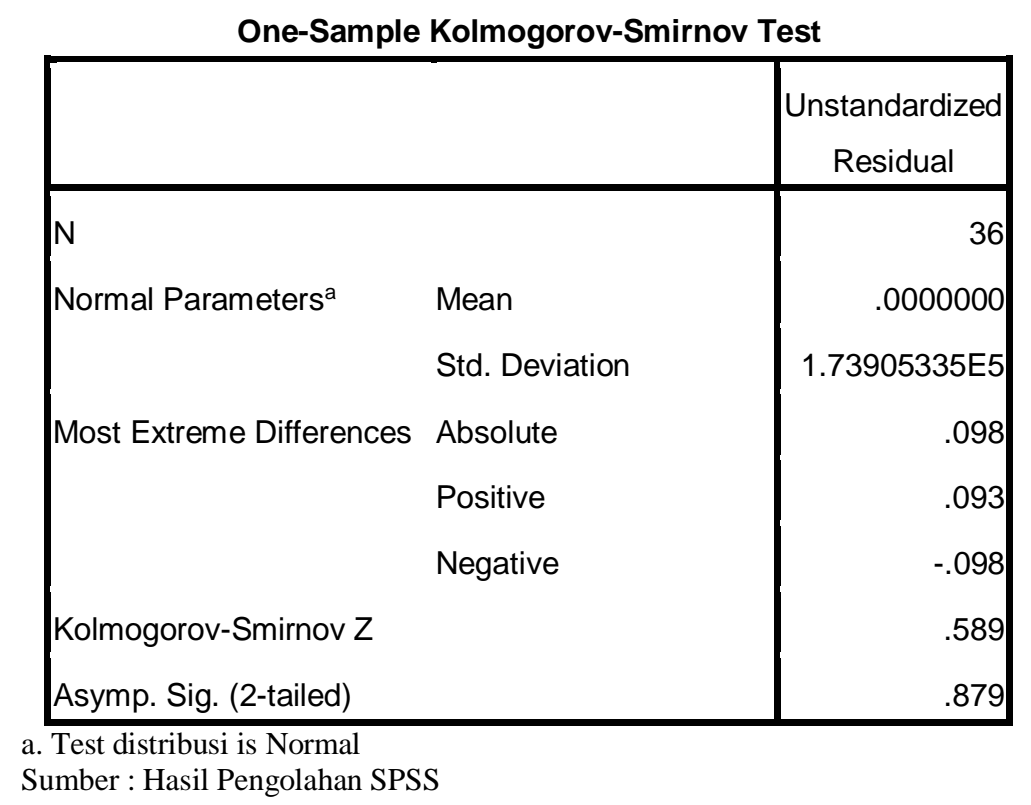

Berdasarkan dari hasil tabel uji K-S, dapat dilihat bahwa besarnya nilai K-S adalah 0,589 dan signifikan pada 0,879 , maka hal ini menunjukan bahwa data residual terdistribusi secara normal karena $>0,05$.

\section{Uji Multikolinearitas}

Menurut Ghozali (2009) uji multikolinearitas digunakan untuk menguji apakah dalam model regresi ditemukan adanya korelasi antar variabel bebas. Apabila inginmenguji adanya multikolinearitas dilihat dari nilai VIF (Variance Inflation Factor) atau nilai tolerance, jika nilai Variance Inflation Factors (VIF) < 10, maka dapat disimpulkan data bebas dari gejala multikolinieritas. Hasil pengujian multikolinieritas data dalam peneltian ini dapat dilihat pata tabel berikut ini : 
Tabel 4.2

Hasil Uji Multikolinearitas

\begin{tabular}{|c|c|c|c|}
\hline \multicolumn{4}{|c|}{ Coefficients $^{a}$} \\
\hline \multirow{2}{*}{\multicolumn{2}{|c|}{ Model }} & \multicolumn{2}{|c|}{ Collinearity Statistics } \\
\hline & & Tolerance & VIF \\
\hline \multirow[t]{3}{*}{1} & (Constant) & & \\
\hline & Pembiayaan Bagi Hasil & .117 & 8.522 \\
\hline & Pembiayaan Sewa & .117 & 8.522 \\
\hline
\end{tabular}

Berdasarkan pada table di atas dapat disimpulkan bahwa masing-masing nilai VIF berada sekitar 1 sampai 10 yaitu 8.522, demikian juga hasil nilai tolerance mendekati 1 atau diatas 0,1 yaitu 0,117 . Dengan demikian dapat dinyatakan bahwa model regresi ini tidak terdapat masalah multikolinearitas.

\section{Uji Heterokedastisitas}

Menurut Ghozali (2009) uji heterokedastisitas digunakan untuk menguji apakah model regresi terjadi ketidaksamaan variasi dari data pengamatan yang satu ke pengamatan yang lain. Apabila ada titik-titik yang membentuk pola tertentu yang teratur, maka telah terjadi heteroskedastisitas, sebaliknya jika tidak membentuk pola tertentu yang teratur maka tidak terjadi homoskedastisitas. Hasilnya dapat dilihat pada gambar 2 berikut ini :

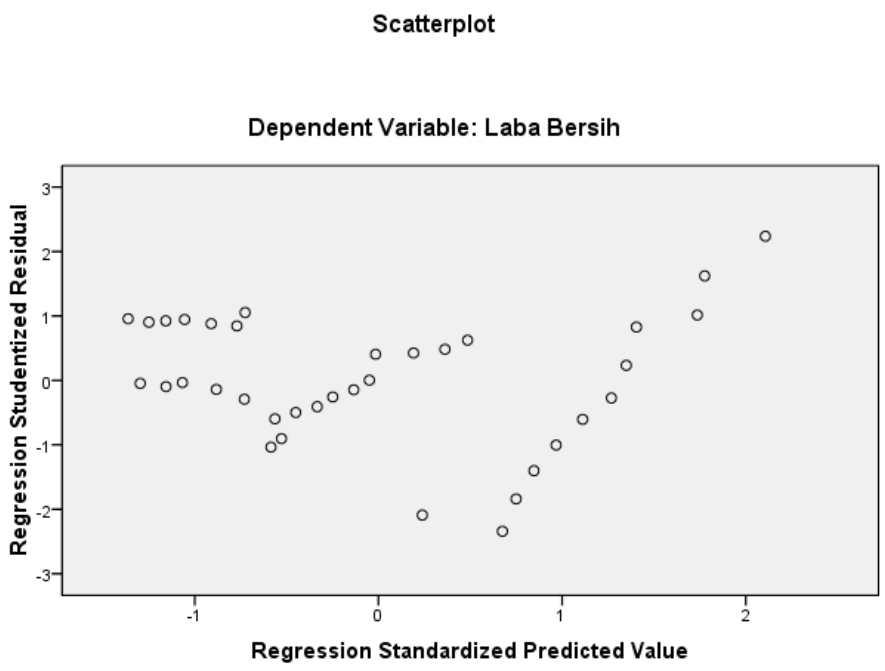

\section{Gambar 4.1}

\section{Hasil Uji Heterokedastisitas}

Berdasarkan gambar di atas dapat dilihat bahwa titik-titik menyebar secara acak (random) serta tersebar di atas maupun di bawah angka 0 pada sumbu Y. Sehingga dapat disimpulkan bahwa tidak terjadinya heteroskedastisitas pada model regresi, sehingga model regresi layak untuk dipergunakan.

\subsection{Regresi Linear Berganda}

Berdasarkan dari hasil uji asumsi klasik yang sebelumnya telah dilakukan, maka syarat untuk melakukan analisis regeresi linier berganda telah terpenuhi. Analisis regresi ini digunakan untuk menguji pengaruh yang diberikan oleh varibael pembiayaan bagi hasil dan 
pembiayaan sewa terhadap laba bersih pada PT. Bank Syariah Mandiri. Hasil pengolahan data pada analisis regresi linier berganda yaitu sebagai berikut :

Tabel 4.3

Coefficients $^{a}$

\begin{tabular}{|c|c|c|c|c|c|c|}
\hline \multirow{2}{*}{\multicolumn{2}{|c|}{ Model }} & \multicolumn{2}{|c|}{ Unstandardized Coefficients } & \multirow{2}{*}{$\begin{array}{c}\begin{array}{c}\text { Standardized } \\
\text { Coefficients }\end{array} \\
\text { Beta }\end{array}$} & \multirow[b]{2}{*}{$\mathrm{T}$} & \multirow[b]{2}{*}{ Sig. } \\
\hline & & $\mathrm{B}$ & Std. Error & & & \\
\hline \multirow[t]{3}{*}{1} & (Constant) & 1673104.004 & 915856.831 & & 1.827 & .077 \\
\hline & Pembiayaan Bagi Hasil & -.004 & .024 & -.043 & -.152 & .880 \\
\hline & Pembiayaan Sewa & -1.794 & .589 & -.868 & -3.047 & .005 \\
\hline
\end{tabular}

a. Dependent Variable: Laba Bersih

Sumber : Hasil Pengolahaan SPSS

Berdasarkan tabel coefficients di atas dapat dibentuk persamaan model regresi linier berganda sebagai berikut :

$$
\begin{aligned}
& Y=a+b_{1} x_{1}+b_{2} x_{2} \\
& Y=1.673 .104,004+-.004+-1.794
\end{aligned}
$$

Dimana :

$$
\begin{array}{ll}
\mathrm{Y} & =\text { Laba Bersih } \\
\mathrm{X}_{1} & =\text { Pembiayaan Bagi Hasil } \\
\mathrm{X}_{2} & =\text { Pembiayaan Sewa }
\end{array}
$$

\subsection{Uji Hipotesis}

Pengujian hipotesis dilakukan untuk mengetahui seperti apa pengaruh dan tingkat signifikan masing-masing variabel independen terhadap variabel dependen baik itu dilakukan secara parsial maupun simultan.

\subsubsection{Uji t}

Uji t ini digunakan untuk menguji hipotesis secara parsial, dengan kata lain dilakukan untuk mengetahui signifikan tidaknya pengaruh yang diberikan oleh variabel independen secara parsial terhadap variabel dependen. Berdasarkan hasil analisis dapat diketahui hasil uji t yaitu sebagai berikut :

\section{Tabel 4.4}

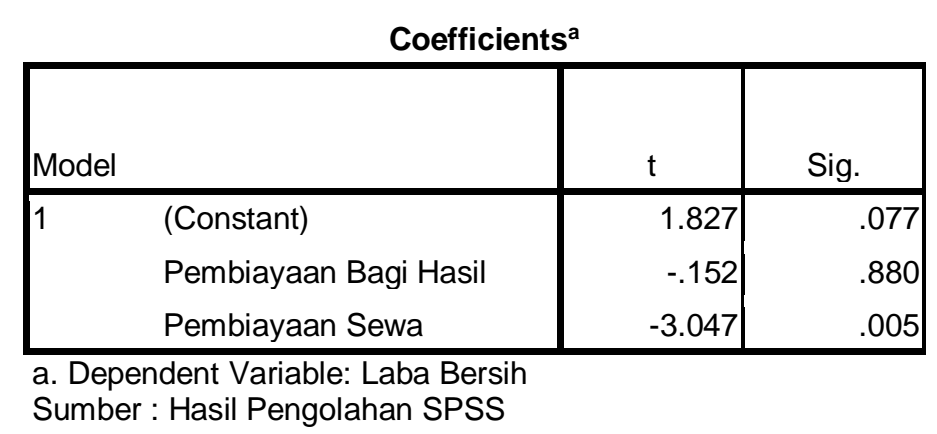

Berdasarkan hasil tabel di atas, dapat diketahui bahwa varibael pembiayaan bagi hasil diperoleh nilai $t_{\text {hitung }}$ sebesar $-0,152$ dan nilai $t_{\text {tabel }}$ sebesar 2,034. Hal ini menunjukkan bahwa $t_{\text {hitung }}<\mathrm{t}_{\text {tabel }}(-0,152<2,034)$. Dan untuk nilai signifikansinya, diperoleh nilai signifikan untuk pembiayaan bagi hasil sebesar 0,880 dan hal ini menunjukkan bahwa nilai signifikan $0,880>$ 0,05. Dari penjelasan tersebut maka dapat disimpulkan bahwa H0 diterima dan Ha ditolak, 
dalam arti secara parsial pembiayaan bagi hasil tidak berpengaruh dan tidak signifikan terhadap laba bersih PT. Bank Syariah Mandiri.

Sedangkan untuk vatiabel pembiayaan sewa dapat diketahui bahwa hasil uji $t_{\text {hitung }}$ adalah sebesar $-3,047$ dan nilai $t_{\text {tabel }}$ sebesar 2,034. Hal ini menunjukkan bahwa $t_{\text {hitung }}<t_{\text {tabel }}(-$ $3,047<2,034$ ). Dan untuk nilai signifikansi pembiayaan sewa diperoleh sebesar 0,005, hal ini menunjukkan bahwa nilai signifikan $0,005<0,05$. Dari keterangan tersebut maka dapat disimpulkan bahwa $\mathrm{H} 0$ diterima dan Ha ditolak, dalam arti secara parsial pembiayaan sewa tidak berpengaruh dan signifikan terhadap laba bersih PT. Bank Syariah Mandiri.

\subsubsection{Uji F}

Uji $\mathrm{F}$ digunakan untuk melihat pengaruh variabel independen terhadap variabel dependen secara simultan. Dimana hipotesis statistik yang diajukan taraf signifikannya $\alpha=0,05$, dan apabila signifikannya $<0,05$ maka variabel independen berpengaruh terhadap variabel dependen secara simultan dan sebaliknya. Berikut tertera hasil uji $\mathrm{F}$ yang telah dilakukan :

\section{Tabel 4.5}

ANOVA $^{b}$

\begin{tabular}{|ll|r|r|r|r|r|}
\hline \multicolumn{1}{|l|}{} & Sudel of Squares & Df & Mean Square & F & Sig. \\
\hline 1 & Regression & 2307062677398.198 & 2 & $1.154 \mathrm{E} 12$ & 35.962 & $.000^{\mathrm{a}}$ \\
& Residual & 1058507291256.800 & 33 & $3.208 \mathrm{E} 10$ & & \\
& 3365569968654.999 & 35 & & & \\
\hline
\end{tabular}

a. Predictors: (Constant), Pembiayaan Sewa, Pembiayaan Bagi Hasil

b. Dependent Variable: Laba Bersih

Sumber : Hasil Pengolahan SPSS

Berdasarkan tabel di atas dapat diketahui bahwa $F_{\text {hitung }}>F_{\text {tabel }}$ yaitu 35,962 > 3,28 dan nilai signifikansi 0,000 < 0,05. Hal ini menunjukkan bahwa berarti H0 ditolak dan Ha diterima, dan berarti variabel pembiayaan bagi hasil dan pembiayaan sewa secara simultan berpengaruh signifikan terhadap laba bersih PT. Bank Syariah Mandiri.

\subsubsection{Uji Koefisien Determinasi $\left(\mathbf{R}^{2}\right)$}

Uji koefisien digunakan untuk mengetahui seberapa persentase sumbangan pengaruh variabel independen $(\mathrm{X})$ secara serentak terhadap varibael dependen $(\mathrm{Y})$. Nilai koefisien determinasi adalah antara $0-1$. Jika $\mathrm{R}^{2}$ yang diperoleh dari hasil perhitungan menunjukkan semakin besar mendekati satu, maka dapat dikatakan bahwa sumbangan dari variabel independen terhadap variabel dependen semakin besar. Hasil koefisien determinasi tergambar sebagai berikut :

Tabel 4.6

Model Summary

\begin{tabular}{|l|r|r|r|c|}
\hline Model & $\mathrm{R}$ & R Square & \multicolumn{1}{c|}{$\begin{array}{c}\text { Adjusted R } \\
\text { Square }\end{array}$} & $\begin{array}{c}\text { Std. Error of the } \\
\text { Estimate }\end{array}$ \\
\hline 1 & $.828^{\mathrm{a}}$ & .685 & .666 & 179097.679 \\
\hline
\end{tabular}

a. Predictors: (Constant), Pembiayaan Sewa, Pembiayaan Bagi Hasil

b. Dependent Variable: Laba Bersih

Sumber : Hasil Pengolahan SPSS

Berdasarkan hasil tabel di atas diperoleh nilai $\mathrm{R}$ Square sebesar 0,685 dan nilai Adjusted R Square sebesar 0,666, yang mana ini menunjukkan bahwa pengaruh dari 
pembiayaan bagi hasil dan pembiayaan sewa terhadap laba bersih PT. Bank Syariah Mandiri yaitu sebesar sebesar $68,5 \%$, dan sisanya $31,5 \%$ dipengaruhi oleh faktor lain yang tidak diteliti dalam penelitian ini.

\subsection{Pembahasan}

Berdasarkan penelitian yang telah dilakukan, diperoleh hasil pengaruh pembiayaan bagi hasil dan pembiayaan sewa terhadap laba bersih Bank Syariah Mandiri, berikut pembahasannya :

\subsubsection{Pengaruh Pembiayaan Bagi Hasil Terhadap Laba Bersih PT. Bank Syariah Mandiri}

Berdasarkan hasil penelitian pada tabel 4.4 menunjukkan bahwasanya Pembiayaan bagi hasil $\left(\mathrm{X}_{1}\right)$ tidak memberikan pengaruh dan tidak signifikan terhadap laba bersih, dan dari hasil analisis penelitian yang dilakukan ini menjelaskan bahwa perubahan tingkat pembiayaan bagi hasil yang disalurkan oleh PT. Bank Syariah Mandiri tidak akan berpengaruh terhadap laba bersih yang akan diperoleh dari nasabah. Dengan kata lain pembiayaan bagi hasil belum tentu mempengaruhi peningkatan laba bersih walaupun pembiayaan yang disalurkan besar. Alasan tidak berpengaruhnya pembiayaan bagi hasil terhadap laba bersih dalam penelitian ini bisa saja disebabkan karena memiliki resiko yang tinggi atau biaya yang dikeluarkan dalam pengelolaan pembiayaan bagi hasil lebih tinggi dari pada jenis lainnya. Sehingga menyebabkan pendapatan bagi hasil yang diperoleh dari penyaluran pembiayaan bagi hasil belum secara optimal diperoleh dan belum mampu mengimbangi biaya-biaya yang akan dikeluarkan dikarenakan adanya resiko macet yang dihadapi oleh PT. Bank Syariah Mandiri.

\subsubsection{Pengaruh Pembiayaan Sewa Terhadap Laba Bersih PT. Bank Syariah Mandiri}

Berdasarkan hasil penelitian pada tabel 4.4 menunjukkan bahwasanya Pembiayaan sewa $\left(\mathrm{X}_{2}\right)$ tidak memberikan pengaruh dan signifikan terhadap laba bersih, dan dari hasil analisis penelitian yang dilakukan ini menjelaskan bahwa perubahan tingkat pembiayaan sewa yang disalurkan oleh PT. Bank Syariah Mandiri tidak akan berpengaruh secara signifikan terhadap laba bersih yang akan diperoleh dari nasabah. Dengan kata lain pembiayaan sewa belum tentu akan mempengaruhi peningkatan laba bersih walaupun pembiayaan sewa yang disalurkan besar. Alasan tidak berpengaruhnya pembiayaan sewa terhadap laba bersih dalam penelitian ini dikarenakan kurang optimalnya dalam peengelolaan pembiayaan yang disalurkan kepada para nasabah PT. Bank Syariah Mandiri, selain itu juga bisa disebabkan karena kurang minat atau masih kurang pahamnya para nasabah terhadap pembiayaan sewa tersebut.

\subsubsection{Pengaruh Pembiayaan Bagi Hasil dan Pembiayaan Sewa Terhadap Laba Bersih PT. Bank Syariah Mandiri}

Berdasarkan hasil penelitian pada tabel 4.5 menunjukkan bahwasanya Pembiayaan bagi hasil $\left(\mathrm{X}_{1}\right)$ dan Pembiayaan sewa $\left(\mathrm{X}_{2}\right)$ secara bersama-sama atau simultan memiliki pengaruh yang signifikan terhadap laba bersih (Y), dengan kata lain pembiayaan bagi hasil dan pembiayaan sewa akan mempengaruhi peningkatan laba bersih PT. Bank Syariah Mandiri walaupun pembiayaan yang disalurkan memiliki resiko. Alasan berpengaruhnya pembiayaan sewa terhadap laba bersih dalam penelitian ini dikarenakan Bank Syariah Mandiri dalam pengelolaan penyaluran dana dan saat meminimalisir tingkat resiko dalam bentuk pembiayaan sudah dilakukan secara optimal sehingga mampu meningkatkan pendapatan bank yang akan mempengaruhi peningkatan laba secara simultan pada PT. Bank Syariah Mandiri. 


\section{Kesimpulan dan Saran}

\subsection{Kesimpulan}

Berdasarkan hasil penelitian yang dilakukan, maka kesimpulan yang dapat diambil yaitu :

1. Hasil penelitian menyatakan pembiayaan bagi hasil secara parsial tidak berpengaruh dan tidak signifikan terhadap laba bersih PT. Bank Syariah Mandiri.

2. Hasil penelitian menyatakan pembiayaan sewa secara parsial tidak berpengaruh dan signifikan terhadap laba bersih PT. Bank Syariah Mandiri.

3. Hasil penelitian menyatakan pembiayaan bagi hasil dan pembiayaan sewa secara simultan mempunyai pengaruh signifikan terhadap laba bersih PT. Bank Syariah Mandiri.

\subsection{Saran}

Berdasarkan kesimpulan yang telah penulis buat, maka adapun saran yang disampaikan yaitu :

1. Diharapkan agar pihak manajemen PT. Bank Syariah Mandiri harus lebih serius dan melakukan penyusunan strategi yang lebih baik dalam melakukan penyaluran pembiayaan bagi hasil dan sewa sehingga nantinya akan mampu meningkatkan laba berisih perusahaan.

2. Pada penelitian selanjutnya diharapkan bisa dilakukan dengan mengeksplorasi faktorfaktor lain yang mempengaruhi laba bersih selain dari pembiayaan bagi hasil dan pembiayaan sewa.

\section{Referensi}

Ahmad, Fauziah Eva. 2018. Laba Bersih Dari Perspektif Murabahah Dan Ijarah (Studi Pada Bank Umum Syariah Di Indonesia Tahun 2012-2016, Jurnal Ilmiah Manajemen dan Akuntansi

Ali, Zainudin. 2010. Hukum Perbankan Syariah, Edisi 1 Cetakan ke-2, Jakarta: Sinar Gafika Antonio, Muhammad Syafi'I. 2009. Bank Syariah dari Teori Ke Praktek, Jakarta: Gema Insani Press.

Chariri dan Ghazali. 2000. Lembaga-lembaga Keuangan Umat Kontem-porer, Yogyakarta: UII Press.

Ghozali. 2005. Aplikasi Analisis Multivariat dengan Program SPSS. Edisi 3. Semarang : Undip.

Ismail. 2011. Perbankan Syariah, Jakarta: Prenada Media Group.

Karim, Adiwarman. 2014. Bank Islam Analisis Fiqh dan Keuangan, Jakarta: PT. Raja Grafindo.

Kasmir. 2008. Analisa Laporan Keuangan, Jakarta: PT RajaGrafindo Persada.

Muhamad. 2014. Manajemen Dana Bank Syariah, Jakarta: Rajawali Pers.

Muhamad. 2016. Manajemen Pembiayaan Bank Syari'ah, Yogyakarta: UPP STIM YKPN.

Puteri, Deasy Rahmi, dkk. 2014. Pengaruh Pembiayaan Mudharabah, Musyarakah, Murabahah, Istishna Dan Ijarah Terhadap Profitabilitas Pada Bank Umum Syariah Di Indonesia, Jurnal Penelitian Dan Pengembangan Akuntansi, Universitas Sriwijaya.

Rivai, Veithzal. 2013. Commercial Bank Management (Manajemen Perbankan) dari Teori ke Praktik, Jakarta: PT. Raja Grafindo Persada.

Sari, S. P. 2018. Pengaruh Pembiayaan Murabahah, Mudharabah, Ijarah Dan Qrdh Terhadap Tingkat Laba Bersih Pda Bank Umum Syariah Di Indonesia Periode 2014-2017. Jurnal Ekonomi Dan Bisnis, 45. Sugiyono. 2016. Metode Penelitian Manajemen, Bandung: Alfabeta.

Suaidah, I. 2020. Pengaruh Pembiayaan Mudharabah dan Pembiayaan Musyarakah Terhadap Laba Bersih Bank Umum Syariah. Jurnal manajemen dan Inovasi (MANOVA), 20. 
Umam, Khaerul. 2013. Manajemen Perbankan Syariah, Bandung: Pustaka Setia.

Umam, Khotibul. 2016. Perbankan Syariah: Dasar-dasar dan Dinamika Perkembangannya di Indonesia, Jakarta: Rajawali Pers.

Wagiarsita, Rantisa. 2016. Pengaruh Pembiayaan Terhadap Peningkatan Laba Pada Bank Umum Syariah di Indonesia Periode Tahun 2013-2015. Skripsi Institut Agama Islam Neger, Bengkulu.

www.syariahmandiri.co.id

Zainuddin, M. A. 2020. Pengaruh Pembiayaan Mudharabah dan Pembiayaan Musyarakah Terhadap Laba Bersih Pada PT. Bank Syariah Bukopin Periode 2015-2019. 